\title{
Elämästä sanoilla ja sanoissa, jotka pettävät
}

\author{
Stanley Cavell (2010). Little Did I Know. Stanford University Press. 558 s.
}

STANLEY CAVELL kirjoittaa vuolasanaisen omaelämänkerran ja päästyään sivulle 523 hän toteaa: "Me olemme, me elämme, maanpaossa sanoistamme, niistä poispäin kääntyneinä, muukalaisina itsellemme ... tähtiä vailla." Arkikielen filosofi Cavell ei pääse autobiografiassaankaan eroon sanoista eikä niiden itseä muovaavasta vaikutuksesta. Sanat mahdollistavat elämänmuodon, mutta ne myös sysäävät epävarmalle pinnalle. Suuren vaikuttajansa Wittgensteinin tavoin Cavell näkee, että kielen käyttö on juoksua kielen rajoja päin.

Aikuiskasvatuksen näkökulmasta Cavellin tekee ajattelijana kiintoisaksi hänen perusteesinsä siitä, että filosofia on täysi-ikäisten kasvatusta. Tällä Cavell viittaa siihen, että filosofia voi paljastaa arkisen kielenkäytön epäselvän luonteen. Tämän myötä avautuu tilaisuuksia kasvulle. Cavellin luonnehdinnassa filosofian tehtä- vänä on saada reflektoimaton hämärässä vaeltaminen pohdituksi ja punnituksi matkaksi valoisaan. Hänen mukaansa filosofian kielellisen käänteen jälkeen tämän tehtävän tulkinta on kytkeytynyt kielen käytön, ja erityisesti arkisen puheen, tutkimukseen.

Cavell on filosofiassaan yhdistänyt analyyttista mannermaiseen filosofiaan. Hänelle filosofia on keskustelua ja ajatusten uudelleenkehittämistä. Tärkeimpinä keskustelukumppaneinaan hänellä ovat maanmiehensä Thoreau ja Emerson, sekä eurooppalaiset Wittgenstein, J.L. Austin ja Heidegger. Näiden ajattelijoiden omaperäisten ja omintakeistenkin tulkintojen myötä Cavell on päätynyt ajatukseen, jonka mukaan filosofia lähtee liikkeelle arkisesta ja tutusta. Tämän takia mikä tahansa arjen ilmiö voi olla lähtökohta filosofiselle tutkimukselle.

Cavellin mukaan emme näe arkea selvästi. Hänelle arjen tavanomaisuus on tavatonta (extraordinary of the ordinary) ja tavaton on tavallista (ordinary of the extraordinary). Näistä korostuksista käsin hänen omaelämänkertansa on poikkeuksellisen mielenkiintoinen projekti: ihminen, joka korostaa, että mikä tahansa tapahtuma on lähtökohta filosofialle ja mikä tahansa filosofia on kasvattavaa, voi ottaa myös oman elämänsä filosofisen teoretisoinnin kohteeksi.

Miten Cavell suoriutuu oman elämänsä kertomisesta filosofiseen tapaan?

\section{FILOSOFINEN KERTOMUS, KERTOMUKSEN FILOSOFIA}

Perustasolla Little Did I Know on kertomus juutalaisesta pojasta, joka syntyy 1920-luvulla, varttuu lama-aikana, opiskelee musiikkia ja kiinnostuu filosofiasta. Varsinaisen oman ajattelun suuntansa hän löytää kielellisen käänteen myötä, 
toimii Harvardissa professorina, ja luo uraa filosofialla, joka yhdistää kirjallisuutta ja filosofiaa.

Tämäkään ulottuvuus ei ole mielenkiinnoton. Vähintäänkin se tarjoaa joukon akateemisia anekdootteja. Lukija saa tirkistellä, minkälaisia keskusteluja Thomas S. Kuhn kävi kirjoittaessaan Tieteellisten vallankumousten rakennetta tai että elokuvaohjaaja Terence Malick jatko-opiskeli Harvardissa tavoittenaan väitellä Heideggerista aikana, jolloin ajattelija oli tyystin tuntematon Harvardin oppituoleilla istujille.

Cavellin elämäntarinan taustana välkkyvät toinen maailmansota, rotuerottelun Yhdysvallat, ihmisoikeusliikkeen nousu 1960-luvulla, filosofian kielellinen käänne ja sen myötä tuntemus, ettei filosofialla ole enää paluuta entiseen, opiskelu ja toiminta Harvardin ja Berkeleyn akateemisissa ympäristöissä sekä juutalaisena amerikkalaisena kasvaminen. Cavell ei lataa näille ulottuvuuksille poliittisia merkityksiä. Cavellin filosofiakäsityksessä filosofia ei ota kantaa poliittisesti, vaan yrittää analysoida elämänmuodon perusteita. Hänen filosofiansa lähtee ihmiselämästä ja ihmisten kiinnittymisestä sanoihin.

Kiinnostavammaksi kirja käy syvätasollaan. Samalla kun kirjoittaa omaa elämäänsä, Cavell työstää kysymystä, miten omaa elämää kerrotaan, miten syvät henkilökohtaiset tuntemukset ja kokemukset ilmaistaan jaetulla kielellä. Cavellin tapa kertoa elä- mänsä on kannanotto muodon tasolla. Hän merkitsee kirjan katkelmat niiden kirjoittamispäivän mukaan. Omien sanojensa mukaan hän ei halua luoda kuvaa, että elämästä voi kertoa suoraviivaisen narratiiviin. Vaikka omaelämänkerta on kronologinen, se poukkoilee moneen suuntaan ajassa, antautuu filosofiseen pohdintaan ja esittää lukijalleen kysymyksiä. Se on Cavellille tyypillinen strategia, jossa samalla kun kerrotaan, asetetaan lukijalle kysymys, mitä kertominen itse asiassa on.

Cavellin kirja hyödyntää hänen normaaleja kirjoittamisen maneereitaan. Hänen pitkät lauseensa polveilevat ja eksyvät suluissa pohtimaan sivulauseissa esiinnostettuja asioita. Kuten Wittgenstein, myös Cavell esittää lukijalle jatkuvia kysymyksiä, joihin hän joskus palaa, joskus ei. Hänen omaelämänkertansa on samalla kertaa yritys kertoa itseään ja filosofoida omien kokemustensa pohjalta. Tämän takia Cavellin tekstillä on tapahtumiaan laajempaa mielenkiintoa. Se toiminee johdantona niille, jotka haluavat ymmärtää, miten ja miksi Cavell ajattelee. Ainakin kirja on hänen helppolukuisimpiaan.

\section{KIRJA EKSYMISISTÄ JA NIIDEN MERKITYKSISTÄ}

Cavellin mukaan kielen filosofia on niin yleisten väittämien tekemistä, että kuka tahansa kielen puhuja voisi myöntää asian olevan näin. Elämänkerrassaan $\mathrm{Ca}$ vell pyrkiikin koskettelemaan nii- tä asioita, jotka yhdistävät kaikkia. Vaihtoehdot ovat hänelle yleisten, kaikkia koskevien kokemusten kommunikointi ja niiden pohjalta teoretisointi, tai vain häntä koskettava, yksilöllinen ja partikulaarinen kokemus, jota on vaikea jakaa muille eikä resonoi jatkoajatuksia lukijoissaan. Cavell kokoaa kirjaansa minun lukukokemuksessani molempia - sekä yleisempiä huomioita että anekdootteja, jotka vaikkakin hauskoja, ovat yksityisiä, vailla syvempää merkitystä.

Onnistuessaan Cavell pystyy koskettelemaan oman ajattelunsa peruslähtökohtaa. Hänen mukaansa filosofia alkaa silloin, kun olemme eksyksissä, emme tiedä miten tässä tilanteessa suunnistetaan, kun emme ole perillä paikoista. Kertomalla omia kokemuksiaan ja umpikujiaan Cavell herättää lukijassakaan kysymyksen, eikö näissä kokemuksissa ole jotakin yleispätevää: eivätkö kaikki ole joskus samalla tapaa ymmällään elämänsä ja sanojensa edessä?

Cavellin mukaan juuri eksyksissä oleminen herättää halun filosofiaan. Mikäli lukija samaistuu Cavellin tuntemuksiin, on hän jo astunut ison askeleen kohti ajattelua, että eksyksissä oleminen kokemus arjessa ja arjesta - on kutsu ajatteluun, asioiden näkemiseen uudesta näkökulmasta, ja tätä kautta kasvuun.

Tomi Kiilakoski

tutkija, Nuorisotutkimusseura Oulu 